\title{
Role of anti-citrullinated protein antibodies in diagnosis and prognosis of rheumatoid arthritis
}

Mariusz Puszczewicz, Cezary Iwaszkiewicz

Department of Rheumatology and Internal Medicine, Poznań University of Medical Sciences, Poznań, Poland

Submitted: 6 September 2010

Accepted: 1 December 2010

Arch Med Sci 2011; 7, 2: 189-194

DOI: 10.5114/aoms.2011.22067

Copyright () 2011 Termedia \& Banach

\section{Abstract}

Antibodies to citrullinated proteins/peptides (ACPAs) are the second serological marker to have recently been included in the 2010 ACR/EULAR Rheumatoid Arthritis (RA) Classification Criteria, which are focused on early diagnosis and therapy. This review discusses their history and some clinical aspects of ACPAs, focusing on the diagnostic utility of anti-cyclic citrullinated peptide (anti-CCP) antibodies as a marker of RA as compared to the widely used rheumatoid factor (RF). Simultaneously, this review aims to raise physician awareness and interest in anti-citrullinated vimentin antibody (anti-Sa/anti-MCV), another member of the ACPA family, which appears to have a better predictive value as a marker of RA than anti-CCP or RF and correlates closely with disease activity and therapeutic response among patients with RA.

Key words: antibodies to citrullinated protein/peptide, anti-cyclic citrullinated peptide, anti-mutated citrullinated vimentin, anti-Sa, rheumatoid arthritis, American College of Rheumatology.

\section{Introduction}

Rheumatoid arthritis (RA) is the most common inflammatory autoimmune disorder, causing progressive joint destruction as a result of chronic synovitis. In many cases, this systemic disease of unclear etiology leads to a severe disability and a significant deterioration in the quality of life. Its various economic, social and psychological consequences indicate that the prevention, or at least retardation, of irreversible joint damage should be the principal therapeutic aim in RA [1, 2]. Prevention of such damage may be achieved by the very early implementation of aggressive treatments with potentially toxic and expensive drugs [3, 4]. The optimal treatment strategy, which should be started as early as possible and tailored to each individual's expected disease severity, requires access to adequate diagnostic and predictive tools $[5,6]$.

The 1987 American College of Rheumatology (ACR) criteria for the classification of RA were mainly based on clinical manifestations and included parameters rarely met in early disease [7]. Rheumatoid factor (RF), the presence of which was the only serological 1987 ACR criterion, lacks RA specificity and has a low prevalence in new-onset disease [8-10].

Given the above, it has become necessary to identify other diagnostic and prognostic markers of RA that are characterized by high sensitivity and specificity and are more appropriate for the diagnosis of new-onset disease.

\author{
Corresponding author: \\ Mariusz Puszczewicz, MD, PhD \\ Department of Rheumatology \\ and Internal Medicine \\ Poznań University \\ of Medical Sciences \\ 28 Czerwca 1956 St. 135/147 \\ 61-545 Poznań, Poland \\ Phone/Fax: +48 618310317 \\ E-mail: \\ mariuszpuszczewicz@gmail.com
}


Antibodies against citrullinated proteins/peptides (ACPAs) seem to fulfill these requirements. ACPAs are the second serological marker (apart from RF) to have recently been included in the 2010 ACR/EULAR classification criteria for RA, which are focused on early diagnosis and therapy (Table I) [11]. It is therefore a good occasion to recall the history and summarize some clinical aspects of ACPAs in the diagnosis of RA.

\section{Anti-citrullinated protein antibodies}

In $1964-24$ years after Waaler's discovery of the first human autoantibody, rheumatoid factor (RF) [12] - Nienhuis et al. described other RA-specific autoantibodies and called them the anti-perinuclear factor (APF). It was discovered that APFs bind to the proteins of keratohyalin granules in buccal mucosa cells and result in a perinuclear pattern of fluorescence in an indirect immunofluorescence test. In this crucial study, about $50 \%$ of the sera from RA patients were APF-positive, in comparison to only $1 \%$ of the sera from a control population [13]. Fifteen years later, the so-called anti-keratin autoantibodies (AKA), specifically present in rheumatoid sera and reacting with the keratinized tissue of animal oesophageal mucosa, were described by Young et al. [14].
In 1993, the acidic/neutral isoform of filaggrin, an intermediate filament-associated protein (IFAP), was reported to be recognized by RA-specific autoantibodies [15]. When it was shown that both APF and AKA react with human epidermal filaggrin and (pro)filaggrin-related proteins, they were jointly named anti-filaggrin autoantibodies (AFA) [16] Filaggrin is expressed as profilaggrin - a highmolecular-weight insoluble precursor stored in the so-called keratohyalin granules - during the terminal differentiation of the mammalian epidermis [17]. After the granules' dispersion, profilaggrin undergoes a specific dephosphorylation and proteolytic cleavage to release the soluble filaggrin. Eventually, the calcium-dependent enzyme peptidylarginine deiminase (PAD) catalyzes the conversion of arginine residues to citrulline residues in filaggrin [18]. This post-transcriptional modification, known as citrullination or deimination, generates citrulline - the amino acid that has been described as the major component of antigenic determinants recognized by RA-specific autoantibodies [19]. Subsequent experiments using human recombinant filaggrin have revealed that only the citrullinated protein can specifically react with AFA; its non-citrullinated form cannot [20].

Table I. From the 2010 ACR/EULAR classification criteria for rheumatoid arthritis [11]

\begin{tabular}{|c|c|}
\hline $\begin{array}{l}\text { Target population (Who should be tested?): Patients who: } \\
\text { 1. Have at least } 1 \text { joint with definite clinical synovitis (swelling). } \\
\text { 2. With the synovitis not better explained by another disease. }\end{array}$ & Score \\
\hline \multicolumn{2}{|c|}{$\begin{array}{l}\text { Classification criteria for RA (score-based algorithm: add score of categories A-D; } \\
\text { a score of } \geq 6 / 10 \text { is needed for classification of a patient as having definite RA) }\end{array}$} \\
\hline \multicolumn{2}{|l|}{ A. Joint involvement } \\
\hline 1 large joint & 0 \\
\hline 2-10 large joints & 1 \\
\hline 1-3 small joints (with or without involvement of large joints) & 2 \\
\hline 4-10 small joints (with or without involvement of large joints) & 3 \\
\hline$>10$ joints (at least 1 small joint) & 5 \\
\hline \multicolumn{2}{|l|}{ B. Serology (at least 1 test result is needed for classification) $)^{+t}$} \\
\hline Negative RF and negative ACPA & 0 \\
\hline Low-positive RF or low-positive ACPA & 2 \\
\hline High-positive RF or high-positive ACPA & 3 \\
\hline \multicolumn{2}{|l|}{ C. Acute-phase reactants (at least 1 test result is needed for classification) } \\
\hline Normal CRP and normal ESR & 0 \\
\hline Abnormal CRP or abnormal ESR & 1 \\
\hline \multicolumn{2}{|l|}{ D. Duration of symptoms } \\
\hline$<6$ weeks & 0 \\
\hline$\geq 6$ weeks & 1 \\
\hline
\end{tabular}

†'Negative refers to IU values that are less than or equal to the upper limit of normal (ULN) for the laboratory and assay; low-positive refers to $I U$ values that are higher than the ULN but $\leq 3$ times the ULN for the laboratory and assay; high-positive refers to IU values that are $>3$ times the ULN for the laboratory and assay. Where rheumatoid factor (RF) information is only available as positive or negative, a positive result should be scored as low-positive for RF. ACPA - anti-citrullinated protein antibody 
More recently, it has been reported that deiminated (pro)filaggrin, the supposed target of AFA, is not expressed by articular tissues. This filamentassociated protein is probably a cross-reactive autoantigen, not involved in RA [21]. As a result, AFAs have been renamed anti-citrullinated protein antibodies (ACPAs).

In order to define the potential targets for ACPAs, numerous studies have been focused on the detection and identification of deiminated proteins present in rheumatoid tissues. Of special interest are fibrin [22], vimentin [23], fibronectin [24], Epstein-Barr nuclear antigen 1 (EBNA-1) [25], $\alpha$-enolase [26], collagen type I [27], collagen type II [28] and histones [29]. The synovial "citrullinome" is a new term describing the entire set of citrullinated proteins in the inflamed synovium [30].

The isotypes of PAD are localized within the cell as inactive forms of the enzyme. Normal living cells do not contain the relatively high levels of calcium $\left(\mathrm{Ca}^{2+}\right)$ necessary for the activation of PADs. In the case of dying cells, the disintegration of the plasma membrane and organelle membranes causes a strong increase in $\mathrm{Ca}^{2+}$ concentration as a result of extracellular $\mathrm{Ca}^{2+}$ influx and $\mathrm{Ca}^{2+}$ liberation from intracellular stores. This $\mathrm{Ca}^{2+}$ increase can lead to the activation of PADs and eventual citrullination of various proteins. Peptidylarginine deiminases released from the dying cells may also be activated by extracellular $\mathrm{Ca}^{2+}$ [31]. When large-scale cell death occurs, e.g. during inflammation, clearance mechanisms may not be in a position to effectively remove apoptotic remnants. Consequently, the citrullinated proteins come into contact with immune system cells and may initiate the ACPA response. As the presence of deiminated proteins has been demonstrated in a variety of inflammatory conditions, citrullination is widely accepted as a common process associated with inflammation and is non-specific for RA. Therefore, high RA specificity of ACPAs appears to be a result of an abnormal antibody response to citrullinated proteins, which is specific for RA, and most probably depends on the patient's genetic background and environmental risk factors [32, 33].

\section{Clinical aspects}

Along with investigations into the possible role of ACPA response in RA pathogenesis, efforts have also been focused on designing serological tests that could become clinically available for measuring ACPAs. Filaggrin extracted from human epidermis [34] and in vitro citrullinated recombinant filaggrin [20] were primarily used as antigens in enzymelinked immunosorbent assays (ELISAs), but they did not provide adequate standardization due to their heterogeneity. Schellekens et al. designed a synthetic cyclic citrullinated peptide (CCP) and used it as a new antigenic substrate in anti-CCP ELISA to detect ACPAs [35]. Van Venrooij et al. developed a second generation of the test, known as antiCCP2 ELISA, which demonstrates a higher sensitivity for RA than anti-CCP1 and is still the most commonly used test for ACPAs in clinical practice [36]. The anti-mutated citrullinated vimentin (Anti-MCV) ELISA using MCV as the antigenic substrate has been developed to improve detection of the antibody against citrullinated vimentin (anti-Sa), a particular member of the ACPA family of antibodies [37]. Citrullinated vimentin appears to be one of the synovial deiminated autoantigens generated during apoptosis [23].

Rheumatoid factor, commonly regarded as the serological hallmark of RA, may be present in a variety of other rheumatic and non-rheumatic conditions, and also among healthy individuals [8]. In contrast with RF, anti-CCP antibodies have a welldocumented high specificity for RA. Van Venrooij et al. have accumulated anti-CCP2 test results from 144 independent studies related to RA (published between 2002 and 2008) and prepared an overview of the test's diagnostic value [38]. The specificity of anti-CCP2 vs. normal controls was $99 \%$, whereas specificity vs. disease non-RA controls was $94.2 \%$. The sensitivity for established RA was $75.2 \%$ compared with $61 \%$ for early disease. It has been widely observed and accepted that an anti-CCP diagnostic test provides higher RA specificity than IgM-RF, and similar or slightly lower sensitivity in comparison to RF $[38,39]$. Since multiple different methods and cut-off values are commonly used for the determination of RF and its significance, individual studies can be difficult to compare [40]. By contrast, increasing standardization of ACPA measurement was emphasized in the 2010 RA Classification Criteria. The authors suggested that increasingly significant differences in the standardization of ACPA and RF testing may be taken into consideration in further amendments of these criteria [11].

In RF-negative RA patients, the anti-CCP2 test demonstrates sensitivity ranging from about 35\% to $80 \%$ and specificity over $90 \%$ vs. non-RA disease controls [40-43]. Anti-CCP antibodies are associated with a poor prognosis in terms of radiographic joint damage and functional outcomes in patients with seronegative RA and also in recent-onset RA [41-44]. In addition, anti-CCP may be a predictive marker of disease progression to RA in patients with early undifferentiated arthritis (UA) [45]. Thus, anti-CCP2 testing may be helpful in making individualized treatment decisions regarding the early implementation of disease-modifying antirheumatic drugs (DMARDs) in patients with newonset UA [46]. Chibnick et al. observed a strong correlation between a higher titer of anti-CCP and 
shorter time to diagnosis of RA [47]. A steady increase of anti-CCP levels prior to disease onset is probably associated with both quantitative and qualitative changes of ACPA response during the development of RA. Ioan-Facsinay et al. analyzed sera from 81 RA patients, 195 of their unaffected relatives (mainly first-degree), and 91 unrelated control subjects to qualitatively characterize ACPA response in health and disease [48]. Anti-CCP was present in about $91 \%$ of RA patients, $19 \%$ of their healthy relatives and $9 \%$ of healthy controls. Interestingly, anti-Sa antibodies were found with a prevalence of $61 \%$ in anti-CCP-positive RA patients and $0 \%$ in anti-CCP-positive healthy relatives. Moreover, the expression of anti-CCP immunoglobulin isotypes among RA patients was more extensive (1-6 isotypes) in comparison to healthy anti-CCP-positive relatives (1-2 isotypes).

Detection of anti-MCV antibodies has been shown to provide a sensitivity of $62-84 \%$ and specificity of $83-95 \%$ for the diagnosis of RA. Considering these parameters, anti-MCV ELISA seems to have a comparable diagnostic value in RA to that of the anti-CCP2 assay [49-53]. Many authors suggest that anti-MCV/anti-Sa antibodies are a better predictive marker of subsequent high RA severity and radiographic joint damage than anti-CCP2 or RF [54-57]. Since some researchers do not agree with the additional significance of this test in the diagnosis and prognosis of RA, further investigations among different populations and different groups of patients are required $[53,58$, 59]. In contrast with anti-CCP, anti-MCV/anti-Sa titers seem to correlate closely with disease activity and therapeutic response in patients with RA [55]. Therefore, the clinical value of the anti-MCV/anti-Sa test has become a promising research objective.

\section{Conclusions}

The 2010 ACR/EULAR classification criteria for RA give official confirmation for the use of ACPA testing in the diagnosis of RA [11]. Interestingly, both serological markers (RF and ACPAs) are scored equally in these criteria. In light of how recent many of these studies are, one can regard this approach as a kind of scientific caution. One can expect that the well-documented diagnostic and prognostic significance of ACPAs, higher than that of the RF, will soon be formally endorsed, especially with regards to RA of recent onset and $U A$.

\section{References}

1. Whalley D, McKenna SP, de Jong Z, van der Heijde D. Quality of life in rheumatoid arthritis. Br J Rheumatol 1997; 36: 884-8.

2. Eberhardt K, Larsson BM, Nived K, Lindqvist E. Work disability in rheumatoid arthritis - development over
15 years and evaluation of predictive factors over time. J Rheumatol 2007; 34: 481-7.

3. O'Dell JR. Treating rheumatoid arthritis early: a window of opportunity? Arthritis Rheum 2002; 46: 283-5.

4. Korpela M, Laasonen L, Hannonen P, et al. Retardation of joint damage in patients with early rheumatoid arthritis by initial aggressive treatment with disease-modifying antirheumatic drugs: five-year experience from the FINRACo study. Arthritis Rheum 2004; 50: 2072-81.

5. Steiner G, Nell V, Eberl G, et al. Autoantibodies in very early rheumatoid arthritis: diagnostic tools or pathogenic players? Arthritis Res Ther 2003; 5: 118.

6. Landewé R. Predictive markers in rapidly progressing rheumatoid arthritis. J Rheumatol Suppl 2007; 80: 8-15.

7. Arnett FC, Edworthy SM, Bloch DA, et al. The American Rheumatism Association 1987 revised criteria for the classification of rheumatoid arthritis. Arthritis Rheum 1988; 31: 315-24.

8. Newkirk MM. Rheumatoid factors: what do they tell us? J Rheumatol 2002; 29: 2034-40.

9. Eberhardt KB, Svensson B, Truedsson L, Wollheim FA. The occurrence of rheumatoid factor isotypes in early definite rheumatoid arthritis - no relationship with erosions or disease activity. J Rheumatol 1988; 15: 1070-4.

10. van Zeben D, Hazes JM, Zwinderman AH, Cats A, van der Voort EA, Breedveld FC. Clinical significance of rheumatoid factors in early rheumatoid arthritis: results of a follow up study. Ann Rheum Dis 1992; 51: 1029-35.

11. Aletaha D, Neogi T, Silman AJ, et al. Rheumatoid Arthritis Classification Criteria. An American College of Rheumatology/European League Against Rheumatism Collaborative Initiative. Arthritis Rheum 2010; 62: 2569-81.

12. Waaler, E. On the occurrence of a factor in human serum activating the specific agglutination of sheep red corpuscles. Acta Pathol Microbiol Scand 1940; 17: 172-88.

13. Nienhuis RL, Mandema E, Smids C. A new serum factor in patients with rheumatoid arthritis: the antiperinuclear factor. Ann Rheum Dis 1964; 23: 302-5.

14. Young BJ, Mallya RK, Leslie RD, Clark CJ, Hamblin TJ. Antikeratin antibodies in rheumatoid arthritis. Br Med J 1979; 2: 97-9.

15. Simon M, Girbal E, Sebbag M, et al. The cytokeratin filament-aggregating protein filaggrin is the target of the so-called "antikeratin antibodies", autoantibodies specific for rheumatoid arthritis. J Clin Invest 1993; 92: 1387-93.

16. Sebbag M, Simon M, Vincent C, et al. The antiperinuclear factor and the so-called antikeratin antibodies are the same rheumatoid arthritis-specific autoantibodies. J Clin Invest 1995; 95: 2672-9.

17. McKinley-Grant LJ, Idler WW, Bernstein IA, et al. Characterization of a cDNA clone encoding human filaggrin and localization of the gene to chromosome region 1q21. Proc Natl Acad Sci USA 1989; 86: 4848-52.

18. Vossenaar ER, Zendman AJW, van Venrooij WJ. Citrullination, a possible functional link between susceptibility genes and rheumatoid arthritis. Arthritis Res Ther 2004; 6: 1-5.

19. Schellekens GA, de Jong BA, van den Hoogen FH, van de Putte LB, van Venrooij WJ. Citrulline is an essential constituent of antigenic determinants recognized by rheumatoid arthritis-specific autoantibodies. J Clin Invest 1998; 101: 273-81.

20. Girbal-Neuhauser E, Durieux JJ, Arnaud M, et al. The epitopes targeted by the rheumatoid arthritis-associated antifilaggrin autoantibodies are posttranslationally generated on various sites of (pro) filaggrin by 
deimination of arginine residues. J Immunol 1999; 162: 585-94.

21. Cantaert T, De Rycke L, Bongartz T, et al. Citrullinated proteins in rheumatoid arthritis: crucial but not sufficient! Arthritis Rheum 2006; 54: 3381-9.

22. Masson-Bessière C, Sebbag M, Girbal-Neuhauser E, et al. The major synovial targets of the rheumatoid arthritisspecific antifilaggrin autoantibodies are deiminated forms of the alpha- and beta-chains of fibrin. J Immunol 2001; 166: 4177-84.

23. Vossenaar ER, Després N, Lapointe E, et al. Rheumatoid arthritis specific anti-Sa antibodies target citrullinated vimentin. Arthritis Res Ther 2004; 6: R142-50.

24. Chang X, Yamada R, Suzuki A, Kochi Y, Sawada T, Yamamoto K. Citrullination of fibronectin in rheumatoid arthritis synovial tissue. Rheumatology (Oxford) 2005; 44: 1374-82.

25. Pratesi F, Tommasi C, Anzilotti C, Chimenti D, Migliorini P. Deiminated Epstein-Barr virus nuclear antigen 1 is a target of anti-citrullinated protein antibodies in rheumatoid arthritis. Arthritis Rheum 2006; 54: 733-41.

26. Kinloch A, Tatzer $V$, Wait $R$, et al. Identification of citrullinated alpha-enolase as a candidate autoantigen in rheumatoid arthritis. Arthritis Res Ther 2005; 7: R1421-9.

27. Suzuki A, Yamada R, Ohtake-Yamanaka M, Okazaki Y, Sawada T, Yamamoto K. Anti-citrullinated collagen type I antibody is a target of autoimmunity in rheumatoid arthritis. Biochem Biophys Res Commun 2005; 333: 418-26.

28. Burkhardt H, Sehnert B, Bockermann R, Engström A, Kalden JR, Holmdahl R. Humoral immune response to citrullinated collagen type II determinants in early rheumatoid arthritis. Eur J Immunol 2005; 35: 1643-52.

29. Hagiwara T, Hidaka Y, Yamada M. Deimination of histone $\mathrm{H} 2 \mathrm{~A}$ and $\mathrm{H} 4$ at arginine 3 in $\mathrm{HL}-60$ granulocytes. Biochemistry 2005; 44: 5827-34.

30. Tabushi Y, Nakanishi T, Takeuchi T. Detection of citrullinated proteins in synovial fluids derived from patients with rheumatoid arthritis by proteomics-based analysis. Ann Clin Biochem 2008; 45: 413-7.

31. Vossenaar ER, Radstake TR, van der Heijden A, et al. Expression and activity of citrullinating PAD enzymes in monocytes and macrophages. Ann Rheum Dis 2004; 63 . 373-81.

32. Vossenaar ER, Smeets TJ, Kraan MC, Raats JM, van Venrooij WJ, Tak PP. The presence of citrullinated proteins is not specific for rheumatoid synovial tissue. Arthritis Rheum 2004; 50: 3485-94.

33. Makrygiannakis D, af Klint E, Lundberg IE, et al. Citrullination is an inflammation-dependent process. Ann Rheum Dis 2006; 65: 1219-22.

34. Palosuo T, Lukka M, Alenius $\mathrm{H}$, et al. Purification of filaggrin from human epidermis and measurement of antifilaggrin autoantibodies in sera from patients with rheumatoid arthritis by an enzyme-linked immunosorbent assay. Int Arch Allergy Immunol 1998; 115: 294-302.

35. Schellekens GA, Visser H, de Jong BA, et al. The diagnostic properties of rheumatoid arthritis antibodies recognizing a cyclic citrullinated peptide. Arthritis Rheum 2000; 43: 155-63.

36. van Venrooij WJ, Zendman AJ. Anti-CCP2 antibodies: an overview and perspective of the diagnostic abilities of this serological marker for early rheumatoid arthritis. Clin Rev Allergy Immunol 2008; 34: 36-9.

37. Bang H, Egerer K, Gauliard A, et al. Mutation and citrullination modifies vimentin to a novel autoantigen for rheumatoid arthritis. Arthritis Rheum 2007; 56: 2503-11.
38. van Venrooij WJ, van Beers JJ, Pruijn GJ. Anti-CCP antibody, a marker for the early detection of rheumatoid arthritis. Ann N Y Acad Sci 2008; 1143: 268-85.

39. Mutlu N, Bicakcigil M, Tasan DA, Kaya A, Yavuz S, Ozden Al. Comparative performance analysis of 4 different anticitrullinated protein assays in the diagnosis of rheumatoid arthritis. J Rheumatol 2009; 36: 491-500.

40. Tuchocka-Piotrowska A, Białkowska-Puszczewicz G, Puszczewicz M. The prevalence and diagnostic significance of aCCP antibodies and rheumatoid factor in rheumatoid arthritis patients. Reumatologia 2007; 45: 59-64.

41. Quinn MA, Gough AK, Green MJ, et al. Anti-CCP antibodies measured at disease onset help identify seronegative rheumatoid arthritis and predict radiological and functional outcome. Rheumatology (Oxford) 2006; 45: 478-80.

42. Shankar S, Grover R, Handa R. Role of anti cyclic citrullinated peptide antibodies in erosive disease in patients with rheumatoid arthritis. Indian J Med Res 2006; 124: 689-96.

43. Alexiou I, Germenis A, Ziogas A, Theodoridou K, Sakkas LI. Diagnostic value of anti-cyclic citrullinated peptide antibodies in Greek patients with rheumatoid arthritis. BMC Musculoskelet Disord 2007; 8: 37.

44. Meyer O, Labarre C, Dougados M, et al. Anticitrullinated protein/peptide antibody assays in early rheumatoid arthritis for predicting five year radiographic damage. Ann Rheum Dis 2003; 62: 120-6.

45. van Gaalen FA, Linn-Rasker SP, van Venrooij WJ, et al. Autoantibodies to cyclic citrullinated peptides predict progression to rheumatoid arthritis in patients with undifferentiated arthritis: a prospective cohort study. Arthritis Rheum 2004; 50: 709-15.

46. van der Helm-van Mil AH, le Cessie S, van Dongen $\mathrm{H}$, Breedveld FC, Toes RE, Huizinga TW. A prediction rule for disease outcome in patients with recent-onset undifferentiated arthritis: how to guide individual treatment decisions. Arthritis Rheum 2007; 56: 433-40.

47. Chibnik LB, Mandl LA, Costenbader KH, Schur PH, Karlson EW. Comparison of threshold cut-points and continuous measures of anti-CCP antibodies in predicting future RA. J Rheumatol 2009; 36: 706-11.

48. Ioan-Facsinay A, Willemze A, Robinson DB, et. al. Marked differences in fine specificity and isotype usage of the anti-citrullinated protein antibody in health and disease. Arthritis Rheum 2008; 58: 3000-8.

49. Dejaco C, Klotz W, Larcher H, Duftner C, Schirmer M, Herold $M$. Diagnostic value of antibodies against a modified citrullinated vimentin in rheumatoid arthritis. Arthritis Res Ther 2006; 8: R119.

50. Soos L, Szekanecz Z, Szabo Z, et al. Clinical evaluation of anti-mutated citrullinated vimentinby ELISA in rheumatoid arthritis. J Rheumatol 2007; 34: 1658-63.

51. Mathsson L, Mullazehi M, Wick MC, et al. Antibodies against citrullinated vimentin in rheumatoid arthritis. Higher sensitivity and extended prognostic value concerning future radiographic progression as compared with antibodies against cyclic citrullinated peptides. Arthritis Rheum 2008; 58: 36-45.

52. Poulsom H, Charles PJ. Antibodies to citrullinated vimentin are a specific and sensitive marker for the diagnosis of rheumatoid arthritis. Clinic Rev Allerg Immunol 2008; 34: 4-10.

53. Damjanovska L, Thabet MM, Levarth EW, et al. Diagnostic value of anti-MCV antibodies in differentiating early inflammatory arthritis. Ann Rheum Dis 2010; 69: 730-2. 
54. Boire G, Cossette P, de Brum-Fernandes AJ, et al. Anti-Sa antibodies and antibodies against cyclic citrullinated peptide are not equivalent as predictors of severe outcomes in patients with recent-onset polyarthritis. Arthritis Res Ther 2005; 7: R592-603.

55. Innala L, Kokkonen H, Eriksson C, Jidell E, Berglin E, Dahlqvst SR. Antibodies against mutated citrullinated vimentin are a better predictor of disease activity at 24 months in early rheumatoid arthritis than antibodies against cyclic citrullinated peptides. J Rheumatol 2008; 35: 1002-8.

56. Mathsson L, Mullazehi M, Wick MC, et al. Antibodies against citrullinated vimentin in rheumatoid arthritis: higher sensitivity and extended prognostic value concerning future radiographic progression as compared with antibodies against cyclic citrullinated peptides. Arthritis Rheum 2008; 58: 36-45.

57. Syversen SW, Goll GL, van der Heijde D, et al. Prediction of radiographic progression in rheumatoid arthritis and the role of antibodies against mutated citrullinated vimentin: results from a 10-year prospective study. Ann Rheum Dis 2010; 69: 345-51.

58. Dejaco C, Klotz W, Larcher H, Duftner C, Schirmer M, Herold M. Diagnostic value of antibodies against a modified citrullinated vimentin in rheumatoid arthritis. Arthritis Res Ther 2006; 8: R119.

59. Luime JJ, Colin EM, Hazes JM, Lubberts E. Does antimutated citrullinated vimentin have additional value as a serological marker in the diagnostic and prognostic investigation of patients with rheumatoid arthritis? A systematic review. Ann Rheum Dis 2010; 69: 337-44. 